\title{
LABOUR REMUNERATION FROM THE PERSPECTIVE OF IMPLEMENTATION OF DECENT WORK CONCEPTION IN EDUCATION SECTOR IN UKRAINE
}

\section{Tsymbaliuk Svitlana ${ }^{1}$}

DOI: dx.doi.org/10.30525/978-9934-571-30-5_24

Abstract. The current paper aims are to substantiate theoretical and methodological principles that reveal the essence of the concept "decent labour remuneration", to develop tools and analyse remuneration policy from the perspective of implementation of decent work conception in education sector in Ukraine. Methodology of research. The analysis of the labour remuneration policy in education sector has been based on the developed indicators using statistical methods, a comparative analysis, an analogue method and a content analysis. Issues of labour remuneration play a key role in theory and practice of the decent work conception. Despite paying focused attention to the issues of remuneration policy by scientists and practitioners, the conception of decent labour remuneration has remained underinvestigated. The conceptual provisions that reveal the essence of the concept "decent labour remuneration" have been formulated. The policy of labour remuneration from the point of view of implementation of decent work principles in education sector in Ukraine has been analyzed. The analysis has shown negative trends, in particular low level, significant lag in wage from other sectors (in particular, finance and insurance, the field of information and telecommunications, etc.), insufficient structure and differentiation of wages. The current policy of labour remuneration leads to demotivation of staff, devaluation of the prestige of pedagogical and scientific activities, loss of employees' interest in work as a way of earning incomes and deepening social inequality. The policy of low wage in the education sector leads to searching work by employees in other sectors with higher level of incomes. The analysis of collective bargaining regulation of remuneration in education sector in Ukraine has shown the low level of

\footnotetext{
${ }^{1}$ Doctor of Economic Sciences, Associate Professor, Professor at Department of Personnel Management and Labour Economics, Kyiv National Economic University named after Vadym Hetman, Ukraine

(C) Tsymbaliuk Svitlana
} 


\section{Tsymbaliuk Svitlana}

it. Many obligations of the social partners are recommendatory rather than mandatory which do not oblige the heads of educational and scientific institutions to implement them. Negative is the fact that some legislative rules have recommendatory nature in the Sectoral Agreement in the education for 2016-2020. There is the lack of specific instruments and responsible people for the implementation of the obligations that leads to non-fulfillment of them, impossibility to control over the implementation of obligations and punish guilty people for breaking the rules. The necessity of improvement of labour remuneration policy in the education sector in Ukraine in order to implement of decent labour remuneration has been proved. The determination of the basic parameters of remuneration must be based on the usage of market and contractual elements for regulation of the level and structure of remuneration, as well as the implementation of innovative approaches and tools to the formation of various components of rewards. Originality. Indicators and standards for estimating remuneration policy from the perspective of implementation of decent work principles at the sectoral level have been worked out. Practical value. Developed indicators and standards for estimating remuneration policy at the sectoral level can be used by ministries, trade union organizations, employers' organizations for analyzing remuneration policy and identifying directions for improvement in order to implement the decent work concept.

\section{Introduction}

Issues of labour remuneration play a key role in theory and practice of the decent work conception. Decent, fair labour remuneration is an important component of the decent work conception. The remuneration plays an essential role in creating high-quality conditions for the reproduction of labour, the professional development of employees and the creation of decent conditions for living. The living standards of employees depend on the amount of reward, which determines their ability to meet requirements, to develop professional level, to maintain health and the ability to work that is obviously a priority from the perspective of implementation of decent work conception.

Despite a constant scientific discussion of decent work issues among academics, as well as an increased interest of state authorities and politicians in this issue, the conception of decent labour remuneration has 


\section{Chapter 12. Economic sciences}

remained underinvestigated. It is necessary to develop tools for estimating remuneration policy from the perspective of implementation of decent work principles at different levels, including sectoral one.

The current paper aims are to substantiate theoretical and methodological principles that reveal the essence of the concept "decent labour remuneration", develop tools and analyse remuneration policy from the perspective of implementation of decent work conception in education sector in Ukraine.

\section{Concept "decent labour remuneration"}

Among the expected results of implementation of the Decent Work Program of ILO in Ukraine for 2016-2019 there is the development and implementation of a remuneration policy with a focus on equal opportunities [14].

Common is the definition of decent labour remuneration as a reward, which provides an expanded reproduction of human and labour potential, economic freedom for an employee and his (her) family [1].

A narrow view of the interpretation of the concept "decent remuneration" is the characteristic of T. Kir'yan, Yu. Kulikov and V. Safonov. The scientists consider that the decent remuneration is adequate earnings under the conditions of motivated productive labour [9, p. 25].

The concept of decent remuneration, according to A. Fedchenko, provides such level that facilitates overcoming poverty and reducing inequality [15, p. 120].

According to these approaches, the only attribute of decent remuneration is its level (in comparison with the living wage) that reduces the significance of other characteristics, including objective differentiation, timeliness of payments, transparency, competitiveness, etc.

N. Volgin explains the concept "decent labour remuneration" wider. According to the approach of the scientist, decent labour remuneration is not only its appropriate level, but also a decent organization, modern forms and systems, culture and equity of formation, payroll accounting, timeliness of payments, etc. [3].

The interpretation of the concept "decent wages", proposed by V. Antoniuk, is close to the previous one. The scientist proposes to consider it in two aspects:

1) as a certain level of remuneration for employee, which provides the normal reproduction of the labour and the development of a human poten- 


\section{Tsymbaliuk Svitlana}

tial of a family of employee, and is adequate to his/her labour force and qualification;

2) as an appropriate remuneration system, which provides provision of social and labour rights of employees, is fair and is carried out using innovations in the organization of payment at enterprises and institutions [2, p. 7].

O. Doronina also departs from the narrowed approach to the consideration of the concept of "decent remuneration". The scientist emphasizes such characteristics of decent remuneration as level of reward that corresponds to world standards and the cost of living; fair wage in comparison with the wage of another employees; compliance with quantity and quality of work; timeliness of payments [8]. Taking into consideration the characteristics, listed by the scientist, decent remuneration is characterized not only by the level, but by the fairness, objective differentiation and timeliness of payments as well.

Analysis of the activity programmes of civil society institutions (political parties, trade union organizations, professional associations, etc.) has allowed us to distinguish the postulates used by them to characterize the concept "decent labour remuneration":

- guaranty of economic freedom for employees;

- timeliness of payments;

- providing conditions for expanded reproduction, professional development, good rest, access to achievements of civilization;

- equitable distribution of incomes between employees and owners (labour and capital);

- objective differentiation of rewards;

- fair taxation of labour incomes;

- development of social partnership concerning regulation of wages;

- providing the priority of wage payment in case of company bankruptcy;

- implementation of innovative remuneration systems, etc.

As we can see, institutions of civil society have deviated from the narrow understanding of the concept "decent labour remuneration". They have appealed to the principles of equity in the distribution of wealth, have added innovative, and market components to the basic characteristics of decent labour remuneration.

We propose to consider the concept "decent labour remuneration" as an organizational and economic mechanism for determining the basic parameters of remuneration, which provides: 
- decent level of remuneration;

- equitable distribution of marginal product between owners and employees;

- objective differentiation of rewards;

- timeliness of payments;

- transparency;

- open-minded attitude towards employees;

- usage of market and contractual elements to regulate the level and structure of remuneration, as well as implementation of innovative approaches to the formation of various components of rewards.

\section{Indicators for estimating remuneration policy at a sectoral level}

Based on the generalization of different approaches to the distinguishing indicators of decent labour remuneration and taking into account the conceptual principles formulated for its interpretation, a set of indicators for estimating remuneration policy from the perspective of implementation of decent work principles at the sectoral level has been developed (table 1).

\section{Table 1}

\section{Indicators for estimating remuneration policy from the perspective of implementation of decent work principles at the sectoral level}

\begin{tabular}{|l|c|}
\hline \multicolumn{1}{|c|}{ Indicator } & Standard \\
\hline The growth rate of real wage in the sector, \% & $\geq 110$ \\
\hline $\begin{array}{l}\text { The ratio between the average wage in the sector and the average } \\
\text { wage in the national economy }\end{array}$ & $\geq 1$ \\
\hline $\begin{array}{l}\text { The percentage of the employees received lower wage than the living } \\
\text { wage in the sector }\end{array}$ & None \\
\hline The share of the base wage in the total wage fund in the sector, \% & $>60$ \\
\hline Arrears of wage in the sector, UAH & None \\
\hline $\begin{array}{l}\text { Regulation of wage issues during collective bargaining and conclusion } \\
\text { of the sectoral agreement in accordance with the Law of Ukraine "On } \\
\text { Collective Agreements and Contracts" }\end{array}$ & Yes \\
\hline $\begin{array}{l}\text { The ratio between the number of obligations of the social partners } \\
\text { for remuneration in accordance with the current sectoral agreement } \\
\text { compared with the number of obligations in accordance with the } \\
\text { previous ones }\end{array}$ & $\geq 1$ \\
\hline $\begin{array}{l}\text { The number of articles of the current sectoral agreement for } \\
\text { remuneration, which contain higher obligations of the social partners } \\
\text { compared with the obligations in accordance with the previous ones }\end{array}$ & All \\
\hline
\end{tabular}


Ending of Table 1

\begin{tabular}{|l|c|}
\hline $\begin{array}{l}\text { The ratio between the number of articles of the sectoral agreement for } \\
\text { labour remuneration contained concrete obligations (figures, amounts, } \\
\text { percentages, documents, procedures, programs) and the total amount } \\
\text { of social partners' obligations for labour remuneration, \% }\end{array}$ & 100 \\
\hline $\begin{array}{l}\text { Usage of analytical methods for evaluating positions and jobs (grading } \\
\text { procedures) in the process of developing wages scale according to the } \\
\text { sectoral agreement }\end{array}$ & Yes \\
\hline $\begin{array}{l}\text { Usage of flexible remuneration system according to the sectoral } \\
\text { agreement }\end{array}$ & Yes \\
\hline $\begin{array}{l}\text { The ratio between the wage of the first rate (in wages scale) and } \\
\text { minimum wage (living wage) according to the sectoral agreement }\end{array}$ & $\geq 1,1$ \\
\hline $\begin{array}{l}\text { The ratio between the wage of the senior rate and the wage of the first } \\
\text { rate according to the wages scales in the sectoral agreement }\end{array}$ & {$[2,3]$} \\
\hline $\begin{array}{l}\text { The ratio between the position salary of chief executive officers (their } \\
\text { deputies) and position salary of clerks according to the scales of } \\
\text { position salary in the sectoral agreement }\end{array}$ & {$[4,12]$} \\
\hline $\begin{array}{l}\text { The ratio between the wages of the two neighbor rates, position sala- } \\
\text { ries of the two neighbor grades, position salaries of the managers and } \\
\text { their deputies according to the wages scales and scales of position } \\
\text { salary in the sectoral agreement, \% }\end{array}$ & $\geq 10$ \\
\hline $\begin{array}{l}\text { Compliance of the list and sizes of additional payments and increases } \\
\text { in accordance with the sectoral agreement with the requirements of } \\
\text { labour legislation and the articles of the general agreement }\end{array}$ & Yes \\
\hline $\begin{array}{l}\text { Availability of the articles in the sectoral agreement concerning } \\
\text { implementation of systems of personnel participation in profits and } \\
\text { (or) in share capital at enterprises }\end{array}$ & Yes \\
\hline $\begin{array}{l}\text { Availability of the articles in the sectoral agreement concerning imple- } \\
\text { mentation of social packages (fringe benefits) at enterprises }\end{array}$ & Yes \\
\hline $\begin{array}{l}\text { Availability of the articles in the sectoral agreement concerning } \\
\text { implementation of social insurance programs (medical, pension, life, } \\
\text { accident, etc.) at enterprises }\end{array}$ & Yes \\
\hline $\begin{array}{l}\text { The percentage of the articles (obligations, rules) of the sectoral } \\
\text { agreement for remuneration implemented by social partners, \% }\end{array}$ & 100 \\
\hline
\end{tabular}

Source: constructed by the author

\section{Analysis of remuneration policy in education sector in Ukraine}

One of the most important indicators characterized remuneration policy is the level and dynamics of real wage. The dynamics of nominal and real wages in the education sector in Ukraine in 2010-2016 are shown in the table 2 . 
Table 2

The dynamics of nominal and real wages

in the education sector in Ukraine in 2010-2016

\begin{tabular}{|l|c|c|c|c|c|c|c|}
\hline \multicolumn{1}{|c|}{ Index } & $\mathbf{2 0 1 0}$ & $\mathbf{2 0 1 1}$ & $\mathbf{2 0 1 2}$ & $\mathbf{2 0 1 3}$ & $\mathbf{2 0 1 4}$ & $\mathbf{2 0 1 5}$ & $\mathbf{2 0 1 6}$ \\
\hline $\begin{array}{l}\text { Nominal wage in the } \\
\text { education sector, UAH }\end{array}$ & 1884 & 2077 & 2532 & 2696 & 2745 & 3132 & 3769 \\
\hline Price index to 2010, \% & 100 & 108 & 108,65 & 100,3 & 111,76 & 166,69 & 169,37 \\
\hline $\begin{array}{l}\text { Real wage in the } \\
\text { education sector, UAH }\end{array}$ & 1884 & 1923,15 & 2330,46 & 2687,98 & 2456,07 & 1878,91 & 2225,31 \\
\hline $\begin{array}{l}\text { The growth rate of real } \\
\text { wage, \% }\end{array}$ & - & 102,08 & 121,18 & 115,34 & 91,37 & 76,50 & 118,44 \\
\hline
\end{tabular}

Constructed by the author according to the data of State Statistics Service of Ukraine [10]

When the nominal wage in education sector in 2010-2016 increased, the growth rate of real wage did not have a stable positive trend. During 2014-2015, due to the significant inflationary tendency the real wage in the education sector significantly declined. It negatively characterizes remuneration policy.

The next indicator for estimating remuneration policy from the perspective of implementation of principles of decent work is the ratio between the average wage in the sector and the average wage in the national economy. Education is one of the lowest paid sectors by the level of wage. Even more, the wage gap in the education sector in comparison with the average wage in the Ukrainian economy increased during 2010-2016. In 2010, the ratio between the average wage in the education sector and the average wage in the national economy was equal to 0.84 . In 2016, this indicator was down to 0.73 [10].

The important indicator characterized the remuneration policy is the percentage of the employees received lower wage than the living wage. During 2010-2016, there is the positive dynamics of this indicator: in 2006, the percentage of the employees received lower wage than the living wage was $6.4 \%$, and in 2016 it was $2.9 \%$ [10], that is, the number of such employees decreased. At the same time, the living wage is not a valid social standard in Ukraine for today, and, therefore, this indicator does not reflect the level of material welfare of employees and the availability of conditions for a full-fledged reproduction of their workforce. The basket of goods (set of food, non-food products and services) for the main social and demographic groups used for calculating the living wage is incomplete, because it does not include essential expenses, in particular for training, treatment, health improvement, rest, etc. 
Therefore, indicators of the level and dynamics of wage in the education sector negatively characterize the remuneration policy from the perspective of decent work. The low level of remuneration, which does not provide an expanded reproduction of the labour force, a significant lag in wage from other sectors (in particular, finance and insurance, the field of information and telecommunications, etc.) demotivates employees, leads to loss of their interest at work as a way of earning incomes. The policy of low wage in the education sector leads to searching work by employees in other sectors with higher level of incomes.

The important indicator for estimating remuneration policy from the perspective of implementation of decent work principles is the share of the base wage in the total wage fund in the sector. According to the data of the State Statistics Service of Ukraine, the share of the base wage in the total wage fund in the education sector is low. It was $56.2 \%$ in 2016 [10], which negatively characterized the remuneration policy (table 1). Considering the fact that a base wage is permanent, the wage structure does not facilitate formation of a sense of stability, safety, which can be a significant demotivational factor for employees in the education sector.

The important indicator for estimating remuneration policy is arrears of wage. The dynamic of this indicator in the education sector in Ukraine during 2010-2017 is shown in the figure 1.

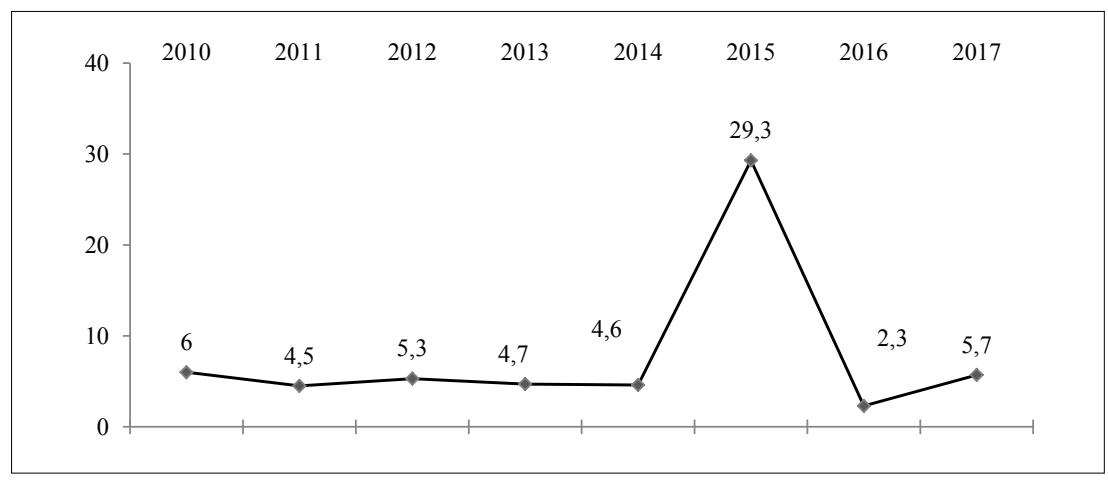

Fig. 1. The dynamic of arrears of wage in the education sector in Ukraine during 2010-2017

Source: constructed by the author according to the data of State Statistics Service of Ukraine [10] 
The maximum of arrears of wage in the education sector was in the period of exacerbation of crisis in Ukraine in 2015. The presence of arrears of wage negatively characterizes the remuneration policy from the perspective of implementation of decent work concept because it does not allow meeting even the minimum needs of employees.

5. Analysis of collective bargaining regulation of remuneration in educa-tion sector in Ukraine

Concerning the level of wage regulation issues during collective bargaining and conclusion of the Sectoral Agreement between the Ministry of Education and Science of Ukraine and the Central Committee of the Ukrainian Employees Union of Education and Science for 2016-2020 [4] in accordance with the legislation [11], the results of estimation are shown in the table 3.

Table 3

\section{The estimation of the regulation of wage issues in the Sectoral Agreement in the education for 2016-2020 in accordance with the legislation}

\begin{tabular}{|l|l|l|}
\hline $\begin{array}{c}\text { Legislative rules of remuneration that must be } \\
\text { regulated by sectoral agreement in accordance } \\
\text { with the article 8 of the Law of Ukraine } \\
\text { "On Collective Agreements and Contracts" }\end{array}$ & $\begin{array}{c}\text { Articles of the } \\
\text { Sectoral Agreement } \\
\text { in the education } \\
\text { for 2016-2020 }\end{array}$ & $\begin{array}{c}\text { The } \\
\text { estimation } \\
\text { of the } \\
\text { regulation }\end{array}$ \\
\hline $\begin{array}{l}\text { Minimum wage guarantees according to the } \\
\text { qualification based on a unified wages scale on a } \\
\text { minimum limit }\end{array}$ & - & no \\
\hline $\begin{array}{l}\text { Minimum sizes of additional payments and } \\
\text { increases taking into account the specifics, } \\
\text { working conditions of certain professional groups } \\
\text { and categories of employees in a sector }\end{array}$ & $\begin{array}{c}6.1 .2-6.1 .4,6.1 .6, \\
6.3 .20,6.3 .21,6.3 .23\end{array}$ & partly \\
\hline $\begin{array}{l}\text { Minimum social guarantees, compensations, } \\
\text { benefits in the field of labour }\end{array}$ & $\begin{array}{l}6.3 .2,6.3 .10,6.3 .11, \\
6.3 .14-6.3 .17,\end{array}$ & partly \\
\hline Utilities and amenities, medical, cultural services & $6.3 .19,6.3 .22,6.3 .24$ & no \\
\hline Organization of health improvement and rest & - & no \\
\hline Conditions for the growth of wage funds & - & no \\
\hline Qualification proportions of salaries & - & no \\
\hline $\begin{array}{l}\text { Providing equal rights and opportunities } \\
\text { for women and men }\end{array}$ & 6.2 .9 & - \\
\hline
\end{tabular}

Constructed by the author according to the data [4] 
According to the data of the table 3, the Sectoral Agreement in the education for 2016-2020 regulates not all the rules of remuneration policy, which must be regulated in accordance with the legislation. The current agreement does not include the articles concerning minimum wage guarantees according to the qualification based on a unified wages scale and qualification proportions of salaries. The Cabinet of Ministers of Ukraine regulates these issues unilaterally, although they must be a subject of collective bargaining. The articles regarding the minimum sizes of additional payments and increases taking into account the specifics, working conditions of certain professional groups and categories of employees in the education sector are regulated partly. Part of the additional payments and increases is also regulated by the legal acts of the Cabinet of Ministers of Ukraine. The Sectoral Agreement in the education does not include articles concerning utilities and amenities, medical, cultural services, and the conditions for the growth of wage funds.

The comparison of the number of obligations of the social partners for remuneration according to the sectoral agreements in the education, concluded during 2007-2016, is shown in the table 4.

Table 4

The number of obligations of the social partners for remuneration according to the sectoral agreements in the education, concluded during 2007-2016

\begin{tabular}{|l|c|c|c|c|c|}
\hline Agreement & $\begin{array}{c}\text { Obligations of } \\
\text { the Ministry } \\
\text { of Education } \\
\text { and Science } \\
\text { of Ukraine }\end{array}$ & $\begin{array}{c}\text { Mutual } \\
\text { obligations/ } \\
\text { partners } \\
\text { have } \\
\text { agreed }\end{array}$ & $\begin{array}{c}\text { Recommendations } \\
\text { of the partners } \\
\text { to heads } \\
\text { of educational } \\
\text { and scientific } \\
\text { institutions }\end{array}$ & $\begin{array}{c}\text { Obligations } \\
\text { of the } \\
\text { Central } \\
\text { Committee } \\
\text { of the } \\
\text { Union of } \\
\text { Employees }\end{array}$ & Total \\
\hline $\begin{array}{l}\text { Sectoral } \\
\text { Agreement for } \\
\text { 2007-2009 [5] }\end{array}$ & 9 & 9 & 10 & 3 & 31 \\
\hline $\begin{array}{l}\text { Sectoral } \\
\text { Agreement for } \\
\text { 2011-2015 [6] }\end{array}$ & 8 & 7 & 20 & 8 & 43 \\
\hline $\begin{array}{l}\text { Sectoral } \\
\text { Agreement for } \\
\text { 2016-2020 [4] }\end{array}$ & 8 & 10 & 25 & 8 & 51 \\
\hline
\end{tabular}

Constructed by the author according to the data $[4 ; 5 ; 6]$ 


\section{Chapter 12. Economic sciences}

According to the data of the table 4, the number of obligations of the social partners for remuneration increased that in general can be considered as a positive practice from the perspective of implementation of decent work principles. The number of obligations of the union significantly increased, in particular due to the strengthening control over compliance with a labour legislation and implementation of obligations for remuneration at institutions and organizations, activation of information, coordination and consulting activities.

The number of obligations mainly increased due to the recommendations of the partners to heads of educational and scientific institutions that indicates the decentralization of collective-contractual regulation of remuneration. This can be considered as a positive step in the context of increasing autonomy of educational institutions. At the same time, the fulfillment of obligations for remuneration by educational and scientific institutions of the public sector dependents on financial capacity, which is determined by public financing.

In addition, the agreements of the partners are recommendatory rather than mandatory that does not oblige the heads of educational and scientific institutions to implement them, and this negatively characterizes the collective-contractual regulation of remuneration. Negative is the fact that some legislative rules [12;13], which must be implemented by all the institutions and organizations of all ownership forms and economic activity, have recommendatory nature in the Sectoral Agreement between the Ministry of Education and Science of Ukraine and the Central Committee of the Ukrainian Employees Union of Education and Science for 2016-2020 [4]. This refers to the additional payments for combining occupations, positions, for extension of the service area, for performance of the duties of temporarily absent employees (article 6.3.6.), payment for work at night (6.3.7), payment for working overtime, work on weekends and public holidays (6.3.9), timeliness of payments (6.3.11), compensation for loss of wages due to payment out of time (6.3.14), indexation of monetary incomes (6.3.15), etc. The provision of a recommendatory nature to the rule concerning the regulation of obligations for remuneration in collective agreements, contracts (6.3.25) is completely unacceptable as well.

The next indicator for estimating remuneration policy from the perspective of implementation of decent work principles is the number of articles in the current sectoral agreement for remuneration, which contain 


\section{Tsymbaliuk Svitlana}

higher obligations of the social partners compared with the obligations in accordance with the previous ones. A comparative analysis of sectoral agreements in the education for 2011-2015 and 2016-2020 showed that the rules of the Sectoral Agreement for 2016-2020 practically duplicate the rules of the previous one. An exception is some recommendations concerning implementation of certain payments (greater basic salaries, additional payments, increases, bonuses, etc.) for certain categories of employees in educational and scientific institutions. At the same time, most of these rules are statutory.

In order to estimate the level of development of collective-contractual regulation of remunaration, the ratio between the number of articles in the sectoral agreement for labour remuneration contained concrete obligations (figures, amounts, percentages, documents, procedures, programs) and the total amount of social partners' obligations for labour remuneration has been determined. The Sectoral Agreement in the education for 2016-2020 contains 51 obligations of social partners concerning the principles and rules for implementing the policy of labour remuneration (table 4 ). Only 23 (45\% of the total amount) obligations contain the concrete ones. The remaining obligations are mutual. They do not include strong commitments or the certain sizes of payments. The lack of specific instruments and responsible people for the imple-mentation of the obligations leads to non-fulfillment of them, impossibility to control over the implementation of obligations and punish guilty people for breaking the rules.

As we have already found out, the current agreement does not include the articles concerning minimum wage guarantees according to the qualification based on a unified wages scale and qualification proportions of salaries. Basic salaries in the education sector are determined on the ground of unified wages scale confirmed by the Act of the Cabinet of Ministers of Ukraine "On remuneration of employees on the basis of the unified wages scale for institutions and organizations of some sectors of the budget sphere" [13].

One of the characteristics of the unified wages scale is the lack of an objective methodology for estimating the complexity of duties and work and professional standards (qualification characteristics for professions and positions) for branches of the budget sphere. That does not allow ranking objectively professions and positions to unified wages scale. This indicates 


\section{Chapter 12. Economic sciences}

a lack of objective differentiation of basic wages in the budget sphere, including the education sector.

The unified wages scale has a rigid framework: each level has a stable basic salary for the certain professions and positions. The unified wages scale also does not take into account the sector particularities and specifics of institutions and organizations. They (institutions and organizations) do not have the opportunity to personalize the salary of employees, taking into account work results, achievements, experience, level of competence, etc.

Basic salaries in the budget sector calculate based on the size of the salary of employee of the 1 st tariff category, which is equal to the living wage. This is a below standard for this indicator (table 1).

Characteristic feature of the unified wages scale is its extremely small range $(1: 4.51)$, since it covers all the categories of employees. For the wages scale with 25 grades this range is negligible and does not provide an objective differentiation of basic salaries of employees. Difference between salaries of the two neighboring grades of the unified wages scale is less than $10 \%$. This indicates leaving out the complexity of labour, responsibility, level of skills of employees of two neighboring grades, and, consequently, lack of objectivity in the differentiation of basic salaries of employees. This negatively characterizes the policy of labour remuneration from the perspective of implementation of decent work conception in the education sector in Ukraine.

The next indicator for estimating remuneration policy from the perspective of implementation of principles of decent work at the sectoral level is compliance of the list and sizes of additional payments and increases in accordance with the sectoral agreement with the requirements of labour legislation and the articles of the General agreement for 2016-2017 [7]. The list and sizes of additional payments and increases in accordance with the Sectoral Agreement in the education for 2016-2020 conform to requirements of labour legislation and the articles of the general agreement. At the same time, as we have already noted, some of them have recommendatory nature: the partners of the agreement do not obligate, but recommend paying them. This negatively characterizes the policy of labour remuneration as well.

Concerning the next indicator (table 1), as far as the education belongs to the budget sector, the Sectoral Agreement for 2016-2020 does not contain articles concerning implementation of systems of personnel participation in profits and in share capital at institutions and organizations. 


\section{Tsymbaliuk Svitlana}

The Sectoral Agreement in the education for 2016-2020 does not contain articles concerning implementation of social packages and social insurance programs (medical, pension, life, accident, etc.) that negatively characterizes the policy of labour remuneration in the education sector from the perspective of implementation of decent work principles.

One of the main indicators for estimating remuneration policy is the implementation of the articles of the sectoral agreement by social partners. Concerning strategic obligations of the Sectoral Agreement in the education for 2011-2015, most of them have remained unfulfilled because of their duplication in the Sectoral Agreement for 2016-2020. As for other obligations, their performance must be investigated separately in each institution of the education.

\section{Conclusions}

Issues of labour remuneration play a key role in the theory and practice of the decent work conception. Despite paying focused attention to the issues of remuneration policy by scientists and practitioners, the conception of decent labour remuneration has remained underinvestigated.

The analysis of the labour remunaration policy in the education sector from the perspective of implementation of principles of decent work in Ukraine has shown negative trends, in particular low level, insufficient structure and differentiation of wages, low level of collective-contractual regulation of remuneration in the education sector, etc. The current policy of labour remuneration leads to prestige devaluation of pedagogical and scientific activities, loss of human capital in the education, deepening social inequality and decrease in the interest of employees in the work results.

The ineffectiveness of the labour remunaration policy and the inefficiencies of institutional framework necessitate improvement of the organizational and economic mechanism for determining the basic parameters of remuneration that will provide a decent remuneration and an objective differentiation of rewards. The determination of the basic parameters of remuneration must be based on the usage of market and contractual elements in order to regulate the level and structure of remuneration, as well as the implementation of innovative approaches and tools for the formation of various components of rewards in the education sector. 


\section{References:}

1. Abuzjarova N. A. (2016). Zarabotnaja plata: pravovoe regulirovanie [Remunaration: legal regulation]. Moscow: RG Press. (in Russian)

2. Antoniuk V. P. (2016). Sotsialna polityka u sferi oplaty pratsi: problemy ta shliakhy zabezpechennia yii hidnoho rivnia (na prykladi promyslovosti) [Social policy in the field of remunaration: problems and ways to providing its decent level (evidence from industry)]. Upravlinnya ekonomikoyu: teoriya ta praktyka. Kyiv: IEP NANU, pp. 3-24. (in Ukrainian)

3. Volgin N. A. Dostojnaja oplata truda kak uslovie i sledstvie dostojnogo truda $v$ innovacionnoj jekonomike [Decent remunaration as a condition and consequence of decent work in the innovative economy]. Retrieved from: http://igpr.ru/ library/volgin_na_dostojnaja_oplata_truda_kak_uslovie_i_sledstvie_dostojnogo_ truda_v innovacionnoj_ $\mathrm{j}$ (in Russian)

4. The Sectoral Agreement between the Ministry of Education and Science of Ukraine and the Central Committee of the Union of Employees of Education and Science of Ukraine for 2016-2020. Retrieved from: https://pon.org.ua/ugoda (accessed 20.08.2018).

5. The Sectoral Agreement between the Ministry of Education and Science of Ukraine and the Central Committee of the Union of Employees of Education and Science of Ukraine for 2007-2009. Retrieved from: https://pon.org.ua/ugoda (accessed 20.08.2018).

6. The Sectoral Agreement between the Ministry of Education and Science of Ukraine and the Central Committee of the Union of Employees of Education and Science, Youth and Sport of Ukraine for 2011-2015. Retrieved from: https://pon.org.ua/ugoda/ (accessed 20.08.2018).

7. General agreement about regulation of the basic principles and rules of implementation of social and economic policy and labor relations in Ukraine for 2016-2017. Retrieved from: http://zakon3.rada.gov.ua/laws/show/n0001120-16 (accessed 20.08.2018).

8. Doronina O. A. (2013). Teoriia ta praktyka formuvannia bahatorivnevoi kadrovoi polityky $v$ konteksti zabezpechennia hidnoi pratsi $v$ Ukraini [Theory and practice of forming a multilevel personnel policy in the context of providing decent work in Ukraine]. Donetsk: DonNU. (in Ukrainian)

9. Kir'yan T. M., Kulikov Yu. M. \& Safonov V. V. (2014). Hidna zarobitna plata u stanovlenni sotsialnoi derzhavy [Decent remunaration in development of social state]. Visnyk sotsialno-ekonomichnykh doslidzhen [Bulletin of socio-economic research], no. 1 (52), pp. 23-31. (in Ukrainian)

10. State Statistics Service of Ukraine. Statistical information. Retrieved from: http://ukrstat.gov.ua (accessed 20.08.2018).

11. On Collective Agreements and Contracts. The Law of Ukraine, dated 01.07.1993, no. 3356. Retrieved from: http://zakon4.rada.gov.ua/laws/ show/3356-12 (accessed 20.08.2018).

12. On remuneration of labour. The Law of Ukraine, dated 24.03.1995, no. 108/95. Retrieved from: http://zakon2.rada.gov.ua/laws/show/108/95-\%D0\% B2\%D1\%80 (accessed 20.08.2018). 
13. On remuneration of employees on the basis of the unified wages scale for institutions and organizations of some sectors of the budget sphere. The Act of the Cabinet of Ministers of Ukraine, dated 30.08.2002, no. 1298. Retrieved from http://zakon4.rada.gov.ua/laws/show/1298-2002-\%D0\%BF (accessed 20.08.2018).

14. Decent Work Program of ILO in Ukraine for 2016-2019. Retrieved from: https:/www.ilo.org/wcmsp5/groups/public/---europe/---ro-geneva/---sro-budapest/ documents/genericdocument/wcms_470684.pdf (accessed 20.08.2018).

15. Fedchenko A. A. (2013). Konceptual'nye osnovy dostojnoj zarabotnoj platy [The conceptual framework of decent remunaration]. Vestnik VGU. Serija: Jekonomika $i$ upravlenie [Vestnik VSU. Series: Economics and Management], no. 1, pp. 119-125. (in Russian) 